\title{
Contribution of School Management Based on Local Values of Tri Hita Karana and Leadership Service
}

\author{
Anak Agung Gede Agung* \\ Program Studi Administrasi Pendidikan, Pascasarjana \\ Universitas Pendidikan Ganesha \\ Singaraja, Indonesia \\ *agung2056@undiksha.ac.id
}

\author{
Ni Made Sugihartini \\ SMK Negeri 2 Singaraja \\ Singaraja, Indonesia \\ made.sugihartini@pasca.undiksha.ac.id
}

\begin{abstract}
Symptoms of the low organizational commitment of teachers at Singaraja-Bali City Middle School encouraged this research. Therefore, this study aims to determine the contribution of school management implementation based on local wisdom values tri hita karana and servant leadership on teacher organizational commitment. This research is ex-post facto. The study population was 428 people and with the sampling technique using the formula Morgan and Krejcie (1970) obtained a sample of 235 teachers. The method of collecting data using a Likert scale model questionnaire. The results of the study data were analyzed by the double regression statistical technique 2 predictors. Based on the analysis of data obtained conclusions (1) there is a significant contribution to the implementation of school management based on tri hita karana local wisdom values on teacher organizational commitment with a contribution of $16.89 \%$, (2) there is a significant contribution of servant leadership to organizational commitment with contribution of $27.39 \%$, (3) there is a significant contribution to the implementation of school management based on local wisdom values tri hita karana and servant leadership on teacher organizational commitment with a contribution of $44.28 \%$.
\end{abstract}

Keywords: organizational commitment, servant leadership, tri hita karana

\section{INTRODUCTION}

Management is a very important thing in all areas of life. With management, the performance of an organization can run effectively and efficiently. With good management, an educational institution will be able to develop optimally the stated goals. Management of education in Indonesia is a central point in realizing educational goals in realizing human resource development (HR). Until now, management of education in Indonesia still has not shown optimal results in realizing professional HR as expected. The problem of management of education is one of the main problems that has caused a crisis in the world of Indonesian education

This condition is caused by the absence of professional education administrators. Therefore, the important thing that must be considered for an educational institution is the existence of professional education administrators. In the management of educational administration, adequate quality of personnel is needed, in the sense of placing the right people in accordance with the capabilities/competencies needed for effective and efficient performance. Management or governance system is one of the factors that can give effect to student learning achievement.

Education based on local wisdom (local genius) tri hita karana is characteristic and cultured education. The implementation of the values of local wisdom tri hita karana in school management will result in quality management, productive and of course environmentally sound. The development of education on the basis of local wisdom values requires a balance and harmony of all school members.

The values of local wisdom tri hita karana should be felt by all school members including the community as stakeholders. Understanding and practicing the elements of tri hita karana, namely parahyangan (harmonious relationship with God), pawongan (harmonious relationship with others), and palemahan (harmonious relationship with the environment), in daily life in the community (school) will be able to realize the vision and the school's mission to produce superior human resources.

Koentjaraningrat [1] states that culture is all things that are owned by humans that are only obtained by learning and using their minds. Culture must be preserved because it has universal elements. The elements of Balinese culture are universal and dynamic are tri hita karana. Tri Hita Karana are the three causes of prosperity and prosperity of human life. The concept of tri hita karana is adi luhung values that have been inherited from generation to generation. In the field of education, the concept of tri hita karana will balance the culture and performance of each individual in every activity in the field of education. Tri Hita Karana can be used as a reinforcer and foster the growth of characterless education that is rooted in Tri Hita Karana's local wisdom.

Principals have a very important role in school management. The progress of school and the high and low quality of graduates cannot be separated from the role of the Principal. The Principal is a leader, both as a leader of an organization, a leader administratively, managerially, and as a learning leader. The leader of the organization is concerned 
with the task of leading an organization consisting of educators / teachers, education staff / staff, and students / students. The leader is administratively associated with the duties he carries out from above and is obliged to manage the administration of the school properly. Leaders are managerially related to their duties and authority to manage various components of school management, such as teachers, staff, students, curriculum, finance, facilities and infrastructure, environment, and so on. Learning leaders are concerned with their duty to ensure and facilitate learning activities to run smoothly and with quality, prepare supporting facilities, be able to carry out supervision, and are primarily able to be role models for teachers, staff, and students, because a leader is not only heard what he says, but what he does.

The nature of exemplary is if what is said is in harmony with what is done. As a leader, the principal must have the skills and character of leadership, such as having a clear vision, responsibility, firmness, wisdom, willingness to sacrifice, and be able to make decisions. A leader also sometimes has to take risks when it's difficult. The role of the Principal as a warrior is related to the various efforts he has made to participate in educating the nation, building the world of education through the schools he leads. A struggle is certainly faced with various challenges, both from within and from outside. Challenges from the inside such as the problem of discipline of teachers, staff, and students, limited funds, facilities and infrastructure. External challenges such as the geographical conditions for those in charge in the interior or remote areas, low public trust, competition between schools. When a school principal manages to build, improve competitiveness, and improve the quality of the school he leads, he will be remembered as a hero. A fighter, his arrival was welcomed, and his departure was mourned. The role of the principal as a servant is in accordance with the philosophy that in essence a leader is a servant. Who should be served? Certainly all stakeholders both internal and external. Internal parties include teachers, staff, and students. While outside parties include parents of students and the community.

In providing services, a waiter must of course provide service of excellence to customers, both internal and external customers. Services that are liked by customers include; friendly, polite, polite, and fast. A school principal must more or less be able to show these characters. In providing services, the Principal is certainly not able to carry out alone, but is assisted by the teacher and his staff. The principal's activities are usually very congested. A school principal must delegate and divide assignments to each of his subordinates. The role of Principals as leaders, fighters, and servants of education in the schools they lead is not easy. This will be greatly influenced by his competence, commitment, responsibility, mentality, creativity and entrepreneurial spirit.

Organizational commitment is a situation where an employee sided with a particular organization and a strong desire to maintain membership in the organization. Robbins states that organizational commitment is partial to certain occupations of individuals, while high organizational commitment means favoring the organization that recruits the individual.

Organizational commitment is an attitude that reflects the extent to which an individual knows and is bound to his organization. Someone who has high organizational commitment will likely see himself as a true member of the organization. In school organizations, teachers are professionals who deal directly with students, so the teacher in carrying out his duties as an educator is able to carry out policies with certain goals and has a strong commitment to the school where he works. A good work environment will make the teacher feel happy and at home in the workplace so that the teacher will produce better work performance and productivity.

So, we cannot deny that school management based on tri hita karana's local wisdom values significantly influences the teacher's organizational commitment. Likewise, the leadership factor of the principal's service influences the teacher's organizational commitment. In addition, the leadership factor of the headmaster's servants greatly contributes to the success in implementing school management based on the values of the local wisdom of tri hita karana.

Based on the explanation on the background of the problem above, this study examines the Contribution of School Management Based on the Values of Local Wisdom of tri hita karana and Servant Leadership on Teacher Organizational Commitment in Singaraja City Middle School.

\section{RESEARCH METHODS}

The design or design of this study is classified as descriptive and correlational research. Descriptive, because researchers try to obtain information relating to the phenomenon observed at this time then describe the data about the object or variable under study [2]. In the research trying to describe data about objects or research variables that exist in State Junior High Schools in Singaraja City, Buleleng, Bali.

Called correlational, because researchers want to explain the relationship or correlation between various variables based on the size of the correlation coefficient [3]. In this connection, Fraenkel and Norman [4] reveal "correlational research attempts to investigate possible relationships among variables without trying to influence those variables". This study involved two independent variables (predictors), namely the implementation of school management based on local wisdom values tri hita karana and leadership of the principal's service, and one dependent variable namely organizational commitment.

The population in this study were all teachers in the State Junior High School in the city of Singaraja, Buleleng, Bali in 2017, which amounted to around 428 people. According to Agung [5] the population is the whole object in a study. The same thing was also expressed by Sugiyono [6] which states that the population is a region of generalization consisting of objects and subjects that have certain qualities and characteristics determined by researchers to be studied and then 
influenced by various factors. Some of the factors that influence it are the local wisdom-based school management tri hita karana and the leadership of the principal's servants. Tri Hita Karana, a local wisdom-based school management, is characterized by character and culture. The implementation of the values of local wisdom tri hita karana in school management will produce quality, productive and certainly environmentally sound school management. Tri hita karana consists of three indicators, namely (1) parhyangan (harmonious relationship of God), (2) pawongan (harmonious relationship with fellow human beings), (3) palemahan (harmonious relationship of the natural environment).

Tri hita karana's local wisdom values should be felt by all school members including the community as stakeholders. The elements in the tri hita karana namely parhyangan, pawongan and palemahan will realize harmonization in the school environment. The Parhyangan element is an element that relates to God, about our hopes, spiritual as well as the spirit of life. Parhyangan is also a place to unite school people and art development places. The element of Pawongan is the concept of harmonizing our fellow school citizens, helping each other and social ethics. Palemahan is a concept of harmonization with the natural environment, how we respect nature and build relationships that are in harmony with nature.

Principals have a very important role in school management. The decline of schools and the high and low quality of graduates cannot be separated from the role of the principal. Quite a number of cases of qualified or professional principals are able to demonstrate good performance and have an impact on the quality of the schools they lead. In other words, the principal is an agent or locomotive for change in the school he leads. The Principal must have 5 (five) dimensions of competence, which include (1) Personality competencies, (2) Managerial competencies, (3) Entrepreneurship competencies, (4) Supervision competencies, and (5) Social competencies. The principal acts as a leader, fighter and education minister.

Servant Leadership is leadership that has the motivation to help others and serve others and involve others in making decisions. There are 10 indicators in servant leadership, namely: (1) listening consisting of (a) communication skills, (b) understanding the group's will, (c) making decisions, (2) empathy consisting of (a) giving empathy to the group, (b ) giving good faith to coworkers, (c) empathetic listeners, (3) healing consisting of: (a) having the power to change, (b) providing health for members who are emotionally ill, (4) awareness consisting of: (a) make a commitment to increase awareness, (b) awareness in understanding the problem, (5) persuasion or persuasion consisting of: (a) having the ability to persuade, (b) the ability to convince others, (c) building consensus with groups, (6) conceptualization consists of: (a) having big dreams, (b) having conceptual thinking, (c) balancing between conceptualizations and daily focus (7) forecasting abilities consisting of: (a) predicting the possibility of a problem, (b) understand the possibilities from the consequences of a decision, (8) the ability to serve consists of: (a) being committed to serving others, (b) emphasizing the use of openness without control, (9) commitment to human growth, 
Singaraja City Middle School maintain the cohesiveness of the school that is built with management oriented tri hita karana local wisdom values which in it implies always maintaining harmonious relations with God, fellow humans, and with the environment wherever we are is located. (2) It is recommended that teachers from the Singaraja City Middle School keep maintaining a mutually serving relationship with the principal and other stakeholders in the school, so as to create a harmonious school climate. (3) it is recommended that principals continue to consistently implementation school management oriented values of local wisdom tri hita karana and leadership services so that the principal remains a role model for teachers and staff in the school. Thus it is expected that the commitment of teachers will be higher and the school will be superior.

\section{REFERENCES}

[1] Koentjaraningrat, Pengantar Antropologi- Jilid I. Jakarta : PT. Rineka Cipta, 2005.

[2] A. Suharsimi, Prosedur Penelitian Suatu Pendekatan Praktek. Jakarta: Rineka Cipta, 1997.

[3] W. Ardhana, "Bacaan Pilihan dalam Metode Penelitian Pendidikan," Proyek Pengembangan Lembaga Pendidikan Tenaga Kependidikan Direktorat Jenderal Pendidikan Tinggi Departemen Pendidikan dan Kebudayaan, Jakarta, 1987.

[4] J.R. Fraenkel and E. Norman, "How to Design and Evalute Researche in Education," Mc Graw-Hill Inc, New York, 1993.

[5] A.A.G. Agung, Metodologi Penelitian Pendidikan. Malang: Aditya Media Publishing, 2014.

[6] Sugiyono, Metode Penelitian Kuantitatif, Kualitatif dan R\&D. Bandung: PT Alfabet, 2016.

[7] A.A.G. Agung, Evaluasi Pendidikan. Singaraja: Undiksha, 2017.

[8] R.K. Greenleaf, Servant Leadership A Journey Into The Nature ofLegitimate Power\& Greatness25th Anniversary Edition. Marwah New

Jersey : Paulist Press, 1999.
Based on the research findings, suggestions can be proposed as follows. (1) It is recommended that teachers at 